TECHNICAL TRANSACTIONS 7/2017

CZASOPISMO TECHNICZNE 7/2017

ARCHITECTURE

DOI: $10.4467 / 2353737$ XCT.17.104.6645

Karolina Dudzic-Gyurkovich (kdudzic-gyurkovich@pk.edu.pl)

Institute of Urban Design, Faculty of Architecture, Cracow University of Technology

\title{
SUBJECT OF URBAN TISSUE CONTINUITY IN DIFFERENT URBANISATION PERIODS IN EUROPE. SELECTED ASPECTS
}

\author{
ZAGADNIENIE CIĄGŁOŚCI TKANKI MIEJSKIEJ W RÓŻNYCH OKRESACH \\ URBANIZACJI W EUROPIE. WYBRANE ASPEKTY
}

\begin{abstract}
$21^{\text {st }}$ century cities, owing to their size, concentration of capital, advanced services and production, are the main centres of the global economy. It is not, however, the domain of exclusively postmodern times. For centuries, cities have played a key role in the development of civilisation, and the processes taking place within them have had an effect on the functioning of entire societies. The urban form we deal with today is a resultant of many determining factors and transformations. This paper presents selected aspects of the urbanisation processes that took place in the past, which even today have their effect on the physical form of towns and cities in Europe. Special attention shall be paid to phenomena, which may influence the coherence of form and the creation of barriers within the urban tissue in a different way.
\end{abstract}

Keywords: Urban form, coherence, urban barrier

\section{Streszczenie}

Miasta w XXI wieku, ze względu na ich wielkość, koncentrację kapitału, nowoczesnych usług i produkcji, są glównymi ośrodkami światowej gospodarki. Nie jest to jednak domena wylącznie czasów ponowoczesnych. Od wieków miasta pełnity kluczową rolę w rozwoju cywilizacji, a procesy nich zachodzące miaty i nadal mają wpływ na funkcjonowanie całych spoleczeństw. Forma urbanistyczna, z którą mamy obecnie do czynienia, jest wypadkową wielu determinujących czynników i przemian. W artykule zostaną przedstawione wybrane aspekty zachodzących w przeszłości procesów urbanizacyjnych, które również obecnie oddziałują na fizyczną postać ośrodków miejskich Europy. Szczególna uwaga zostanie poświęcona zjawiskom w różny sposób mogącym wplywać na spójność formy i tworzenie barier w obrębie tkanki miasta.

Słowa kluczowe: Forma urbanistyczna, spójność, bariera urbanistyczna 


\section{Introduction. Special role of the Ruropean city}

The problem of continuity of urban form is being discussed not only in the field of architectural and urban design, but it seems to touch and influence the processes of everyday life of the citizens. In most of the cases, when the quality of urban environment is perceived as poor, we have to face the lack of harmony and presence of barriers within the urban tissue. The contemporary form of numerous contemporary towns and cities is, however, a result of the operation of staggered forces and phenomena. In case of European cities, amongst which a considerable part have historically shaped quarters, these are processes that were happening over the span of many centuries, which saw planned or spontaneous development and transformations of urbanised areas. A special set of properties that used to be characteristic for cities on the European continent was noticed by e.g. M. Weber, who, based on research into medieval towns, formulated a theoretical model, comprising physical as well as social and political attributes ${ }^{1}$, which were to make them distinct from towns and cities on other continents. The meaning of cities in the historical urban development was also emphasised by L. Benevolo, who classified them as important and characteristic aspects of the cultural heritage [4]. Contemporary deliberations devoted to the phenomenon of 'the European city' go way beyond the framework of the academic discourse ${ }^{2}$. Certain formal and organisational properties ${ }^{3}$ become guidelines for new urbanisation models, such as e.g. the concept of 'a compact city', which is deeply justified by the historical development of cities in Europe $[26,51]$ and is currently implemented as the development policy in compliance with recommendations issued by global organisations ${ }^{4}$. Maintaining the values of 'the European city', which are still significant for its uniqueness, with its simultaneous adaptation to contemporary requirements, is a remedy for the progressing processes of spatial, social, and cultural disintegration, which frequently constitute a consequence of expansive development.

Also today, when the globalisation processes and constant information flow change the distribution of forces, and the area of social contacts translates into a virtual dimension, the real space is still a subject of research carried out in numerous fields of science. The article attempts to present characteristic, selected stages of urbanisation of European cities, Polish cities included, from the morphological perspective, with special emphasis put on the effect of individual phenomena on the physical continuity of the structure observed these days.

He emphasised the need of co-existence of fortifications, a market square (place of trade), a courthouse and independent laws, some form of assembly, and at least partial autonomy [49, p. 38].

2 Although studies of the theoretical model are still in progress in different parts of the world; cf. e.g. [15, 23, 27, 20$]$.

3 Like e.g. compactness of development, hierarchical organisation, presence of historical traces, defined centre and city limits, multi-functionality [5, p. 40].

$4 \quad$ Cf. e.g. $[16,47,38]$. 


\section{The problems of development of contemporary cities}

\subsection{Continuity vs. Fragmentation}

Amongst the problems that contemporary city struggles with, one of the most often discussed issues is the phenomenon of fragmentation, or even capsularisation of this space, which consequently lead to the disappearance of urban qualities. [15, 46, 40, 42, 12$]$.

It is not, however, a new phenomenon, as the first to write about the disturbing condition of American cities in the 1960s was Jane Jacobs, who stigmatised the modernist planning concept implemented at the time. Earlier voices seeking the source of frustration of contemporary man in the city and its social and spatial organisation were coming from e.g. representatives of the Chicago School, who regarded the emerging trend in the sociology of the city as a diagnostic tool of social issues. Space segregation and polarisation observed in cities examined at the time, in theoretical models, assumed the forms of concentric zones [9], sectors [22], or numerous separate centres with specialised functions [19]. It was closely connected with social segregation capable of leading to the domination of one, strongest and most influential group $[9,36,52]$. Today, many researchers find a relation between growing social inequalities and spatial divisions of the city, which constitutes an area of activity of the communities inhabiting it. Such phrases as 'divided cities' [17, 35], 'dual cities' [37], 'polarised', 'fragmented cities' $[8,55]$ regularly appear in the literature of numerous fields of science tackling subjects relating to the city and its functioning.

In the approach of urban planning, the issue of spatial fragmentation as a problem that dominates many others is touched upon in the important publication 'Collage City', where in place of the manner of grasping the contemporary city, the authors propose a mosaic, a collection of different elements ${ }^{5}$ within the scheme of an urban collage, where individual components are not linked to any subordinate compositional concept. The lack of relations, also the spatial ones, between fragments of the city comprehended this way seems to be an inseparable part of this concept. Consequences of fragmentation or division are relatively easy to observe, which was pointed out already by K. Lynch, who stated that residents of the majority of American cities 'are quite aware of the abomination of the world they live in and they often complain about its (...) incoherence and monotony at the same time' [34, p. 3]. Well-developed transportation systems, intended most of all for car traffic, large-scale shopping and industrial facilities, as well as closed private housing estates, contribute to the creation of a landscape where 'no-places' neighbour each other and share places of traditional importance [1].

'objets trouvés', such as e.g. exceptional streets, magnificent public terraces, mysterious and complex buildings [42]. 


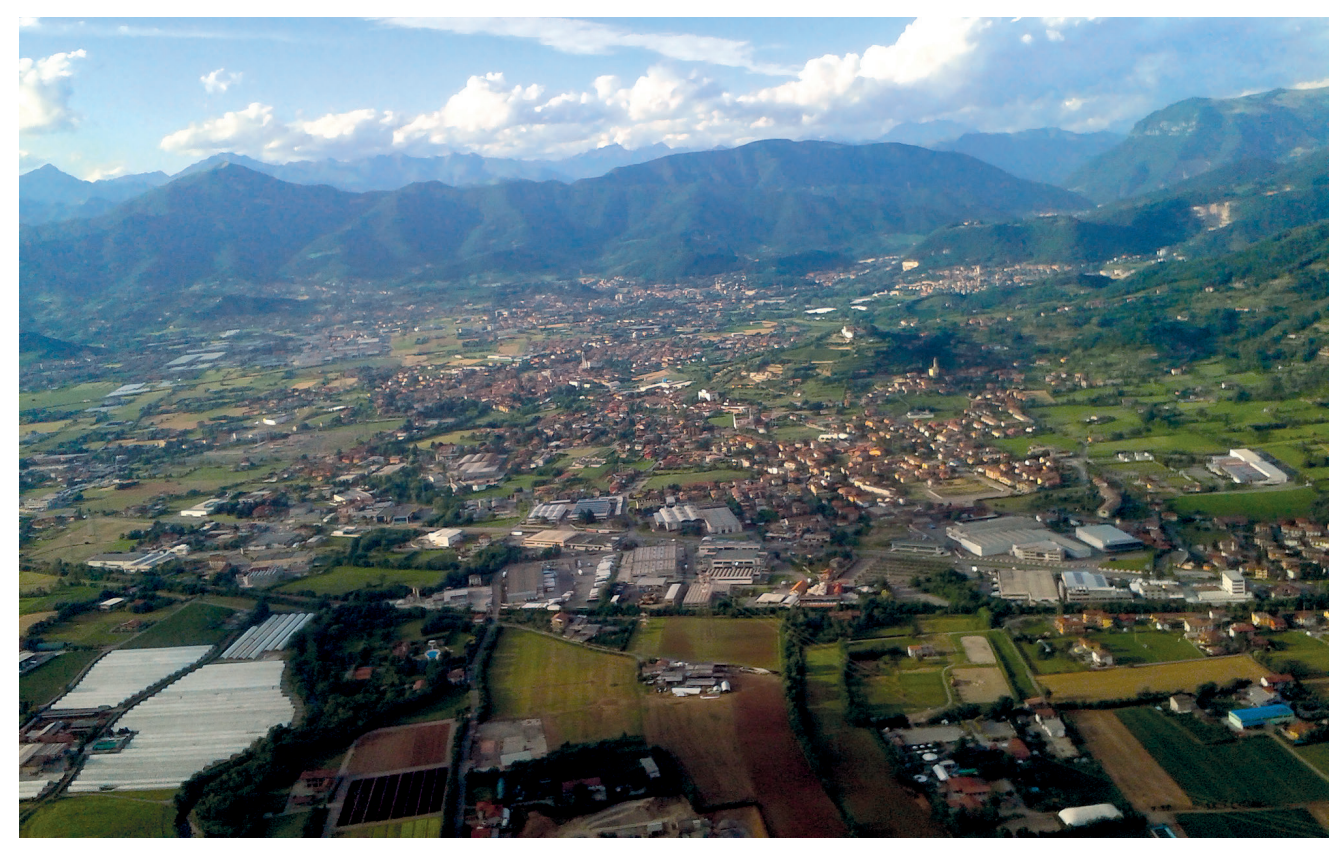

Fig. 1. Urban structure of the vicinity of Milan, exhibiting the features of fragmentation: residential areas neighbour on large service and industrial facilities and farmlands (photo by K. Dudzic-Gyurkovich)

In the opposition, as it were, to the phenomena referred to above, continuity could be simply defined as compactness, cohesion of form, continuation of the built tissue as well as of systems of public spaces, priority of pedestrian accessibility over accessibility of individual means of transport. Continuity can constitute a value of the urban space of the historical origin, as well as the urban space that comes into being in contemporary times.

Structure fragmentation, observable in cities of today, can appear as a factor of numerous different processes, e.g. extensive urbanisation, consuming new areas located further and further from the main urban settlement, or transformations, demolitions, and replacement of the existing tissue ${ }^{6}$. The lack of the sensed coherence of urban spaces can be influenced by processes that occurred sometimes even in the distant past and still determine the development direction and opportunities of the urban organism, which will be discussed hereafter. For decades now, the mathematical approach to the issue of complexity and simultaneous fragmentation of urban structures has been gaining in importance ${ }^{7}$. Analyses of existing systems and theoretical models created by such researchers as m. Batty, B. Hillier, or N. Salingaros, point to the importance of accessibility and continuity most of all of public spaces in the process of forming a well-functioning urban system.

$6 \quad$ The current shape of many European cities was strongly influenced by the period of the World War II and the period of reconstruction that followed it, during which totally opposite concepts were implemented. The W-Z Route in Warsaw, the Nadodrzańska Artery in Szczecin, planned as new axes of the cities, are only two examples of new urban projects implemented in the post-war reality [31].

7 Such theories as 'complexity theory of cities', 'fractal cities', or advanced spatial analysis, such as 'space syntax', cf. e.g. [2, 3, 21]. 


\subsection{Limits, edges, and barriers}

The phenomenon of creating barriers and divisions is inscribed in the nature of creation and transformations of the urban tissue, which is subjected to diversified limitations of physical as well as economic, social and other character. The issue of boundaries and edges of the urban structure has been presented in a very interesting way by e.g. S. Kostof, who differentiated two types of borderlands according to their location towards the urban structure. The first one encompasses cases of shaping the edges in the form of a literary boundary - a wall, as well as - much more frequently encountered today - 'blurred' delimitation of peripheral areas. The second type are all sorts of divisions of the concerning the interior of urbanized area itself, which have been decisive for the special distinctness of specialised functional zones, starting from religion and authorities through commerce, trade, and business. The phenomena of social segregation caused by national, cultural or economic distinctness discussed above fall into the division category understood this very way [28]. In this approach, a certain dichotomy is discernible; an external edge of the urban system is examined predominantly in the categories of physical properties, whereas internal barriers seem to result rather from the social structure, morals, or economic conditions. Nevertheless, there are and still emerge limitations in the contemporary world, which could be defined as urban barriers, influencing the lack of the sensed coherence of space. They constitute barriers most of all at the level of the local traffic and pedestrian traffic, often utilised in a manner that testifies to a certain exterritoriality of the area towards the structure that surrounds it. Such structures as highways, railway areas, large industrial facilities and shopping malls create realistic divisions of the urban tissue frequently contributing to its fragmentation.

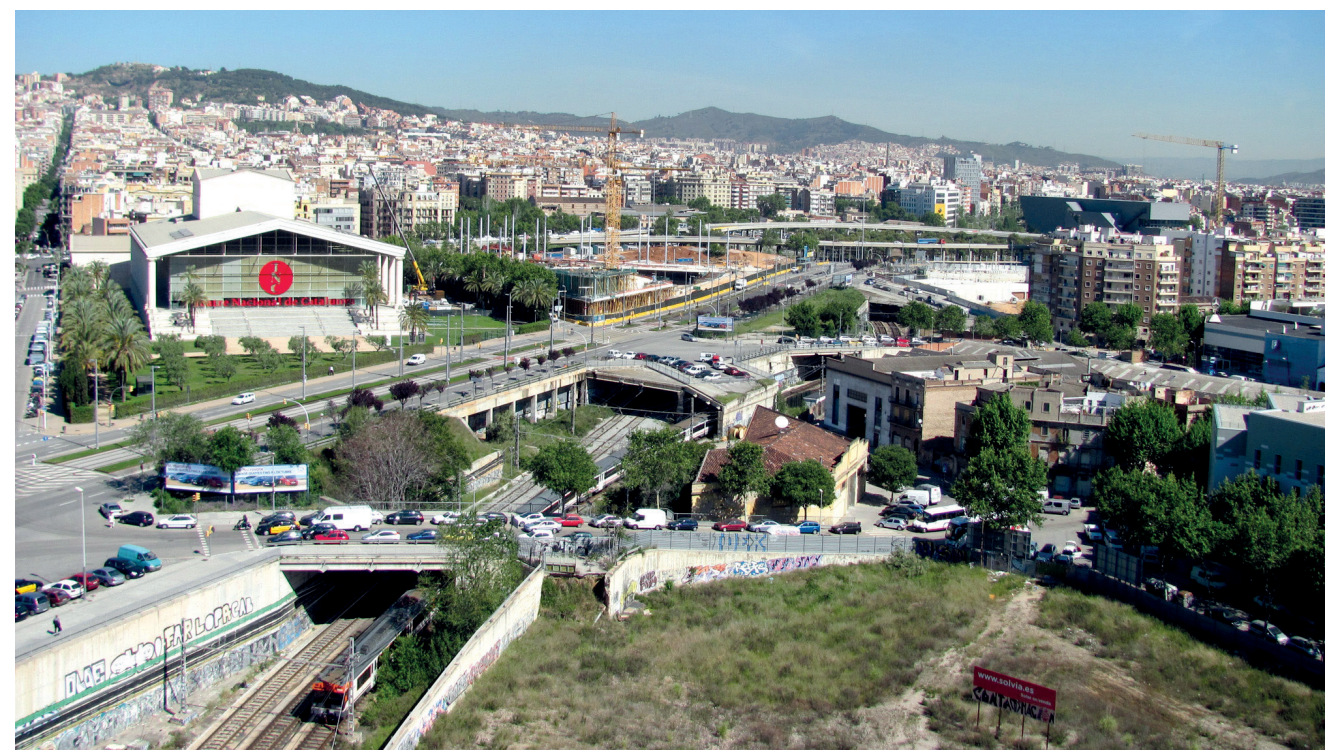

Fig. 2. Barcelona, area located at the edge of the revitalised district of El Poblenou. Continuity of the orthogonal layout is disturbed with transport routes running at several levels (photo by K. Dudzic-Gyurkovich) 


\section{Development of European cities throughout the history.}

\subsection{Before the industrial era}

Amongst the factors, which, in the past, had their effect on the physical form of an urban organism, most of them also functioned as a barrier, which simultaneously enabled the city to develop and constituted its maximum range at the time. The history of urban planning classifies these determinants in many ways, and one of the many theories that deserves to be referred to here is an important theory formulated by T. Tołwiński, who defined a set of influences that have their effect on cities in the process of them coming into being. Explaining the process of building and organising cities basing on the 'urban factors' defined nearly a hundred years ago still seems to be valid to a certain extent. Prior to the modern period, physical barriers for the spatial development of cities included e.g. natural conditions, which in the most fundamental way influenced the form of an urban settlement [45]. Land relief, the presence of rivers, lakes, location at the seashore - all this can still have its effect on the direction of the spatial development of the city, constituting natural barriers that stop the development expansion until the next developmental leap ${ }^{8}$. Processes of shaping development edges at subsequent stages of the development of the city seem to have a crucial effect on its current appearance. Probably the most important factors that influences further development were military conditions, which determined e.g. the compactness of the system and its fitness for fortification. The external edge of compact development marked with the fortification system constituted a measurable limit of the city at the same time. Preserved parts of city walls and defensive systems, which today can be found usually in the very centres of cities, constitute their important historic heritage; traces visible in the names of streets ${ }^{9}$, their routes, or land allotment are of equal importance ${ }^{10}$.

\subsection{Transformations of the industrial era}

The $19^{\text {th }}$ century brought about many changes in the priorities of the process of conscious city design, as well as in the directions assumed by its spontaneous development. Processes of dynamic urbanisation and urban sprawl in Europe were stimulated by the economic development relating to the industrial revolution. A significant increase in the number of city residents entailed the need of relevant transformations of urban spaces, so as to make them

8 Such a leap, in the literature devoted to urban morphology referred to as 'leapfrog', occurs at the time of intensified development of the city, when architecture, usually residential buildings, grow beyond the existing limits, which get absorbed and developed inside the still developing organism, http://www.urbanform.org/ glossary.html (access: 27.01.17).

9 Such names as 'Wall Street' in New York, or 'Rampart Street' in New Orleans, are visible remains of the short period of fortifying American cities. Wooden fortifications fell into decay, or were disassembled in order to obtain materials and fuel [45, p. 38].

10 It is an element which is classified by researchers from the circles of urban morphology as belonging to the so-called 'morphological frame', that is a certain collection of properties and factors which appear in subsequent plans and stages of development of the city. Cf. e.g. [50]. 


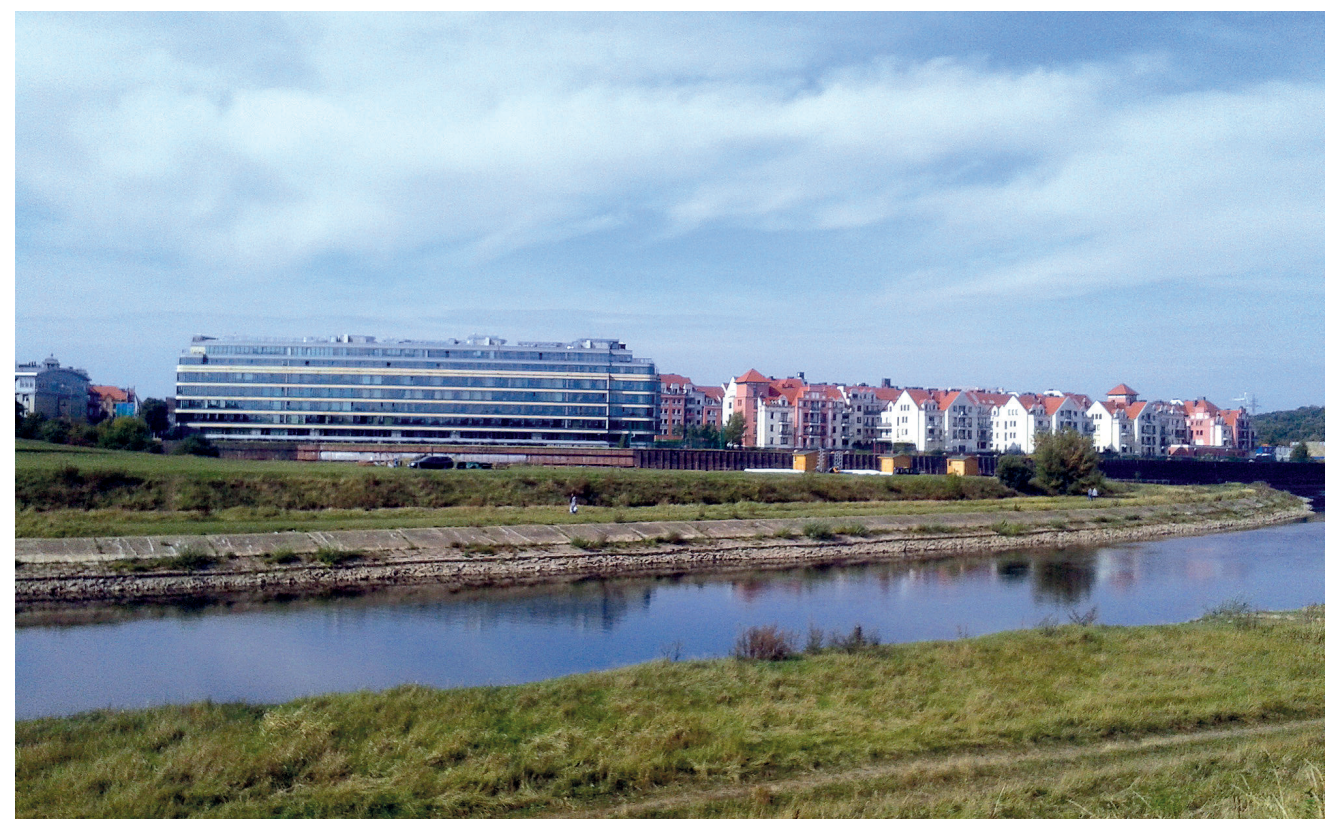

Fig. 3. Location by the river, which constitutes a spatial barrier, determines the development of the central part of Poznań (photo by K. Dudzic-Gyurkovich)

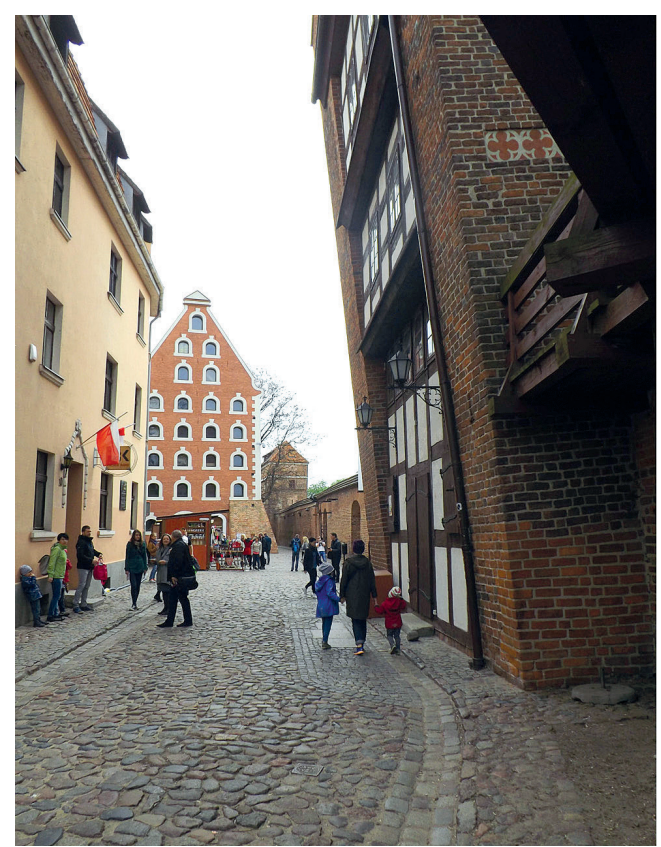

Fig. 4.a. Preserved fragments of fortifications set realistic limits of the Old Town in Torun (photo by K. Dudzic-Gyurkovich)

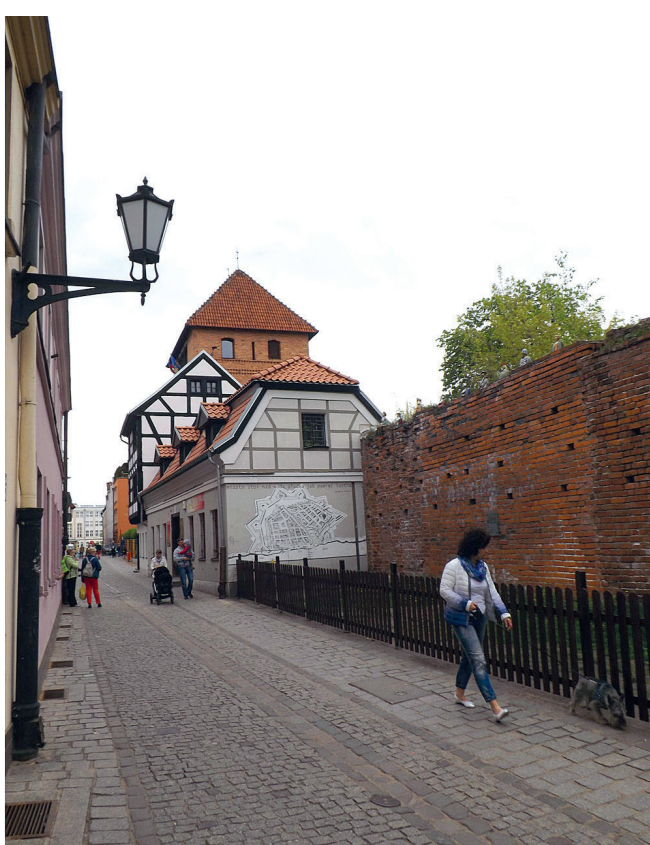

Fig. 4.b. The name and course of Podmurna street (Polish: near the walls) in Torun testifies to the presence of fortifications whose fragments have been preserved to date (photo by K. Dudzic-Gyurkovich) 


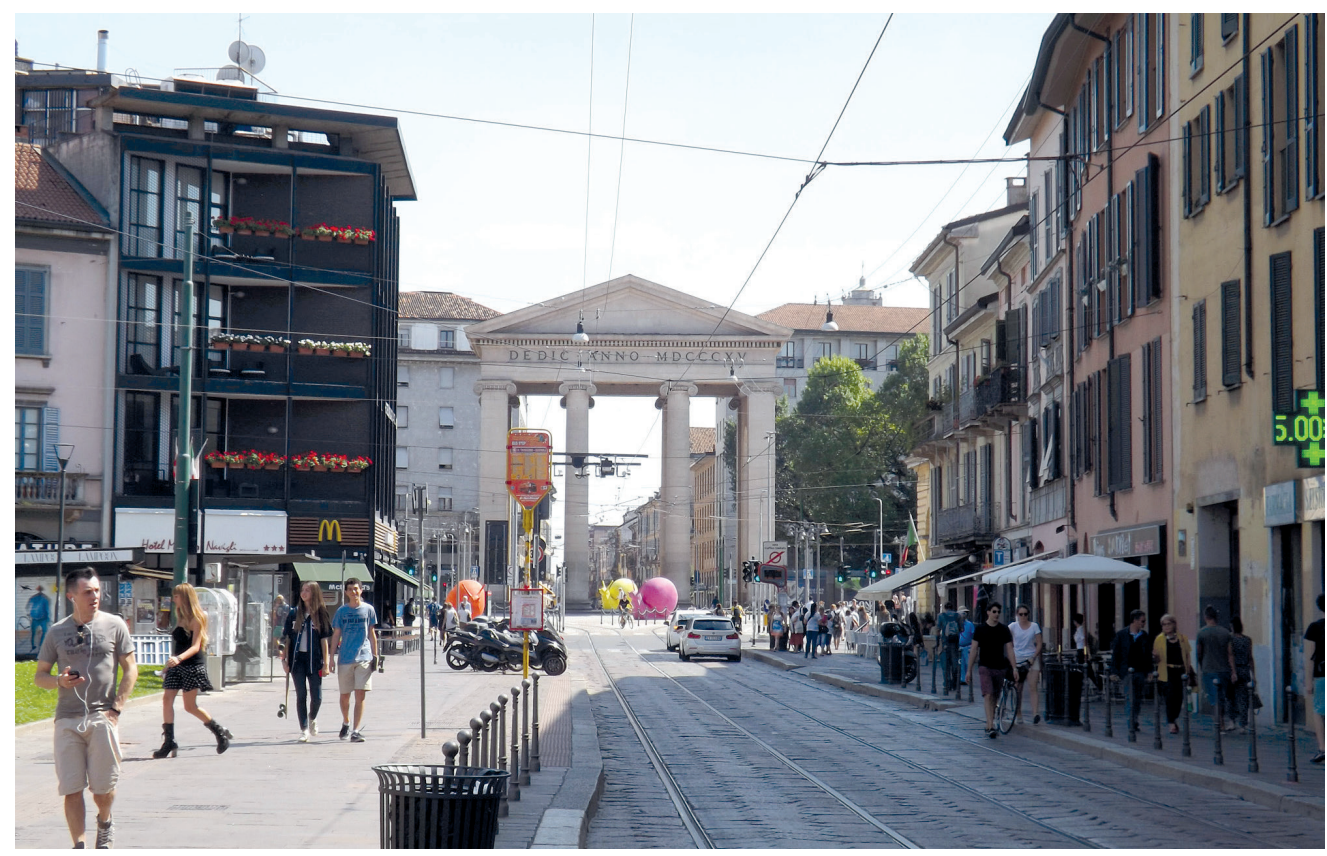

Fig. 4. Milan, view from the historic city towards Porta Ticinese, a place that commemorates one of the gates in the now non-existent city walls. The course of the walls is still legible in the tissue of the city; it is determined by two parallel streets forming characteristic narrow quarters (photo by K.

Dudzic-Gyurkovich)

address the new lifestyle. This fact, as well as the development of warfare techniques, led to a situation where existing fortification systems, most of all dating back to the Middle Ages, now not surrounding entire cities, but only their central parts, became an undesirable barrier hampering and obstructing territorial development. In many cases, they were disassembled in order to allow for harmonious development of city centres, or for their reconstruction. The resulting areas were developed in compliance with the then needs, frequently as boulevards constituting an important element of the emerging transport systems and municipal greenery ${ }^{11}$.

Another important change that had far-reaching effects in the spatial organisation of cities was the appearance and popularisation of railway transport used for transporting goods as well as passengers. At that time, it became necessary to consider it and plan its routes in the operating structure. Changes, and sometimes obstacles in the previously established system of local traffic, relating predominantly to the auxiliary infrastructure, such as embankments, excavations, railway tracks and tractions, from the contemporary point of view, could be classified as barriers with a significant effect on the continuity and coherence of space.

11 A perfect example are Parisian fortifications of Thiers; falling into decay until the end of the $19^{\text {th }}$ century, eventually disassembled in the 1920s. They were replaced by a ring of roads, the so-called Les Boulevards des Maréchaux, which until the construction of the parallel Boulevard Périphérique in the 1970s functioned as a ring road of the city. Similar actions were undertaken e.g. in Vienna, by creating in the years 1858-1872 the Ring and Gürtel boulevards in the place of disassembled fortifications. 


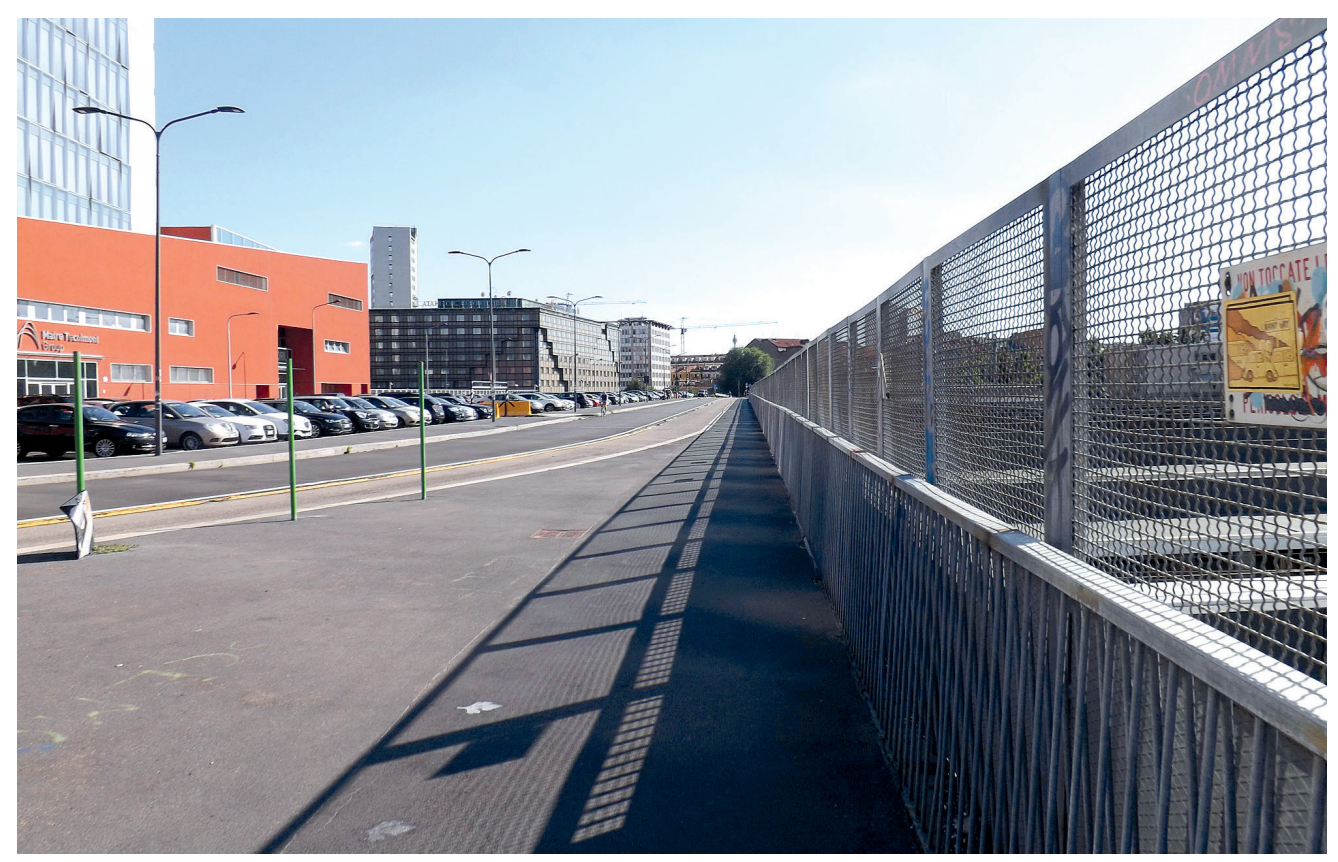

Fig. 5. Milan, view from a parking lot above railway tracks leading to the Porta Garibaldi railway station. The railway tracks, as well as well-developed systems of parking lots constitute a barrier for the surrounding tissue (photo by K. Dudzic-Gyurkovich)

Buildings of railway stations, and most of all railway lines, once intensely utilised, constituted very clear edges, forming the tissue of the city and dividing it. The development of railway progressed over subsequent decades, being an easily accessible as well as mass transportation system $^{12}$. These days, we face a challenge, which is the adjustment of this type of transport to the current needs ${ }^{13}$. The existing, extended systems of railway junctions and sidings are usually utilised to a minor extent, and the grounds occupied by them are closed and excluded from the urban use, still constituting real spatial barriers in the city.

\subsection{Late $19^{\text {th }}$ century, early $20^{\text {th }}$ century - new theories of space organisation}

the appearance of contemporary urban settlements was influenced in a very special way by activities belonging to broadly understood modernism. This trend, developing partially as a negation of the historic, excessively dense tissue, which was no longer able to meet the

1212 As late as in the 1950s, that is until the moment of rapid development of car traffic, railway used to be the dominating means of transport in European cities. Over subsequent decades it was losing its dominance to cars in terms of the transport of people, as well as goods. In socialist states, as a result of definitely slower development of the network of motorways and the activities of the planned economy, comprising the volumes and directions of railway transport, as well, the dominance of railway lasted longer - until the 1970s [18].

13 A developing branch of this type of transport is the high-speed rail, which for several decades now has been gaining in importance, not only in Europe; cf. e.g. [54, 18]. 
needs of the then society, resulted in a revolutionary revaluation of the concept of the city, and solutions implemented at the time frequently evoke controversies and call for revision. Postulates of providing decent living and working conditions, as well as of creating an urban form corresponding more to the modern, dynamic reality, found their reflection in realistic, as well as utopian concepts ${ }^{14}$. The common quality of the sometimes quite different ideas was the principle of functional division, which was given its most radical form in flagship projects by Le Corbusier ${ }^{15}$. According to the new planning doctrine, sanctioned with the deliberations of the CIAM congress and the provisions of the Athens Charter, the city should be functional, i.e. it should have specific areas allocated to residential, industrial, office-related purposes, as well as vast green areas able to provide the designed conditions for leisure and pastimes. The road structure appeared as the superior structure, intended to link individual parts of the city, as well as the city centre with the suburbs. New technical opportunities brought about the actual tiered utilisation of space - wharfs, tunnels, and grade-separated junctions served the purpose of effective separation of functions and improvement of the flow of all types of traffic. In this model, which was implemented over subsequent decades in different forms ${ }^{16}$, barriers disturbing the coherence of the urban tissue were no longer single elements. The previous relations between the open space and buildings were reversed [40,30]. Freestanding structures were located in the open space, limited merely by the edge formed by a transport route or green areas. The continuity of the form of the city was disturbed programmatically.

\section{Summary - contemporary problems of urban planning}

development and transformations of contemporary cities are characterised by the multitude of directions and issues, which, due to the so far never encountered scale of urbanisation ${ }^{17}$, concentrate in urban settlements. From the perspective of transformations of the physical form of the city, the continuity of the urban tissue, and the appearance of barriers, several phenomena seem to be particularly important. Centuries of the development of industrial production-based economy have influenced the urban structure of European cities, leaving behind industrial areas

14 Starting from the concept of 'industrial city' of T. Garnier, remaining in the sphere of plans, or 'garden city' of E. Howard, which has been implemented in numerous European countries, through F.L. Wright's deglomeration 'broadacre city' or A. Soria y Mata's and A. Milutin's 'linear city', to the aforementioned designs by Le Corbusier, in all concepts one can notice a pursuit of clear division of the main functions of the city. Cf. e.g. $[33,6]$.

15 E.g. Ville contemporaine de trois millions d'habitants, (1922), Ville radieuse, (1924), and the never implemented plans for Paris and Barcelona: the Voisin Plan (1925), the Macia Plan (1932), the latter executed in collaboration with a Catalan architect, Joseph Lluís Sert [10].

16 Recommendations of the Athens Charter, published as late as in 1943, had a significant effect on urban planning in the post-war period, not only in Europe. Concepts of modernism, sometimes in their quite grotesque version, were manifested in e.g. large-scale urban projects, wasteful land development, or mass housing construction.

17 According to the data of the World Health Organisation in 2014 54\% of all people lived in urban areas; it is estimated that in 2030 it will be even 66\%. http://www.who.int/gho/urban_health/situation_trends/ urban_population_growth_text/en/(access: 05.02.17). 
and facilities, which, in the era of post-industrial economy, have become useless. As P. Lorens observes, 'the effect of deindustrialisation processes are also dramatic social consequences, such as very high unemployment rates, immense growth of delinquency, and physical degradation of entire vast areas of the urban space' [32, p. 13]. Revitalisation or re-development of such territories constitutes a serious task, which can have a positive effect on the harmonisation and coherence of the city's appearance. Improvement of the quality of grounds that used to be invested into, in global terms, is inscribed in tendencies, which aim to prevent excessive spread of unstructured suburban development, today referred to as 'the urban sprawl'. The development of advanced means of transport, especially the constant increase in the number of passenger cars, is the result as well as one of the causes of the urban sprawl and of locating satellite housing estates further and further from the city centre. Cities on the American continent were one of the first - already in the 1950s - to experience the phenomenon referred to above, which is connected not only with the expansion of extensive forms of development, but also with the dispersion and degradation of downtown areas ${ }^{18}[24,46]$. The lack of continuity in the land development constitutes an inseparable quality of this development system, which currently refers to the majority of European cities, as well [16]. Strategies that are to stop or tame this development model assume different forms, from the concept of 'compact city' ${ }^{19}$, which is oriented towards the form of the city, through 'smart city', 'eco-city', 'creative city', to 'connected city', which is a vision of a coherent city of the $21^{\text {st }}$ century.

The dominance of individual transport, regarded as a priority for many decades of conscious planning, is a complex problem, with multiple consequences. One of them is the creation of barriers inside the urban structure in places where extended transportation routes dominate other types of land use. Heavy car traffic contributes to the marginalisation of the role of public space, and areas adjacent to motorways often are degraded or remain undeveloped due to multiple issues, such as noise, exhaust fumes, or difficulty in crossing the barrier. These are not the only phenomena that create 'the dead edges' of the urban tissue. The group of broadly understood barriers within an urban form includes e.g. fenced residential enclaves or large-scale shopping malls. In each of those cases, a part of the space is demarcated and separated - excluded from public use. Today, privatisation of public space is a broadly encountered phenomenon, manifesting itself very strongly in contemporary spaces of consumption, which compete with the city, assuming social activities traditionally undertaken within the urban environment. Phenomena relating to the imminent globalisation, development of the knowledge-based economy and information society, also contribute to breaking traditional relations within the built space [48]. The return to the concept of urbanity, postulated for many years now, is manifested in a tangible way in the compactness of structure, the block development, or the hierarchical sequence of streets and squares [41]. The actual public space, despite its sometimes quite surprising transformations, or even despite the announcement of its fall, still constitutes the most natural and accessible field of study devoted to the condition of the contemporary city.

18 Which has been already tackled by J. Jacobs, who pointed out that once compact areas with diversified functions change and degenerate in the direction of homogenous, unfriendly structures [24].

19 Cf. e.g. $[26,38]$. 


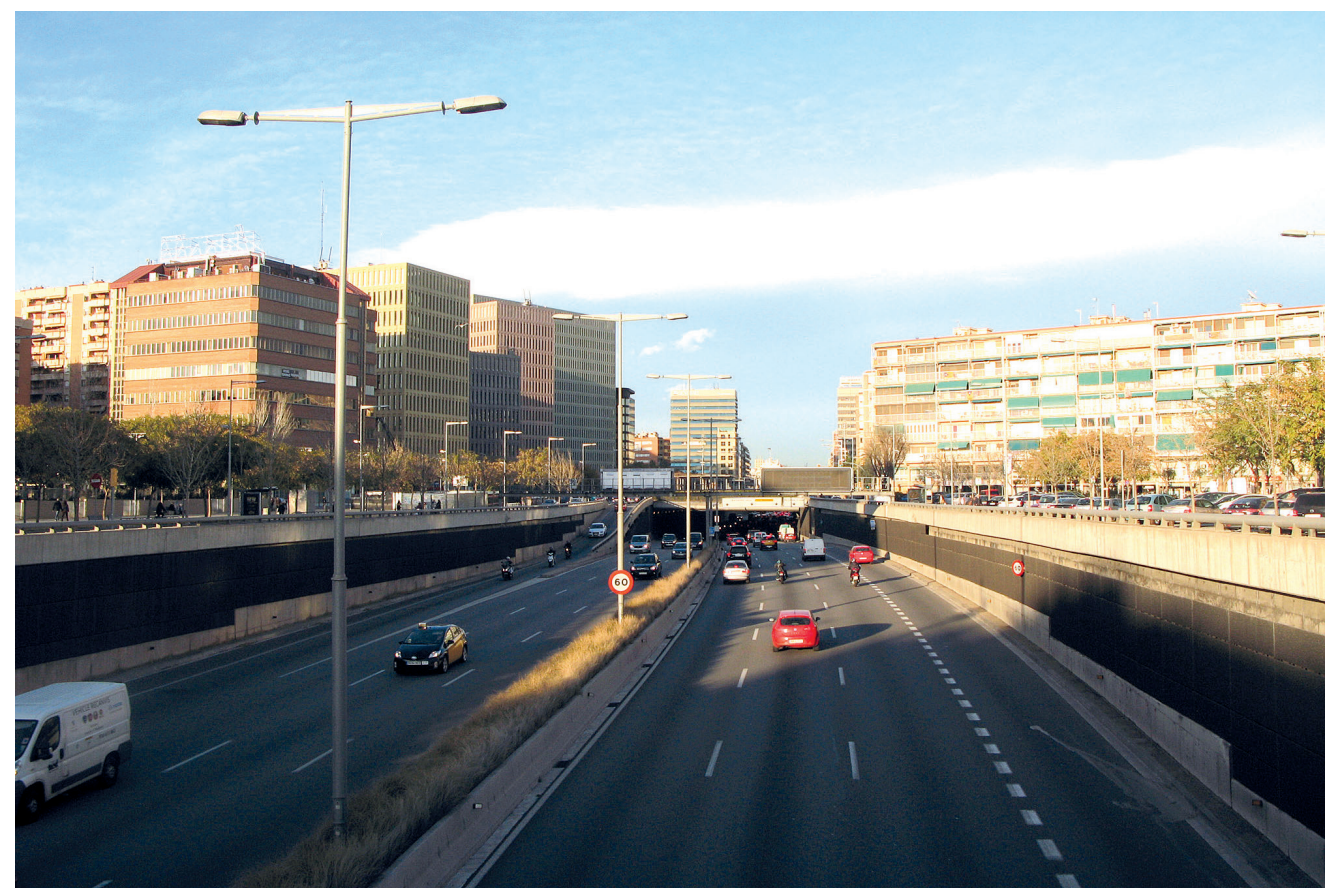

Fig. 6. Barcelona, the main road ( Gran Via de les Corts Catalanes) running nearly across the entire city, intersects the neighbouring areas of compact urban development (photo by K. Dudzic-Gyurkovich)

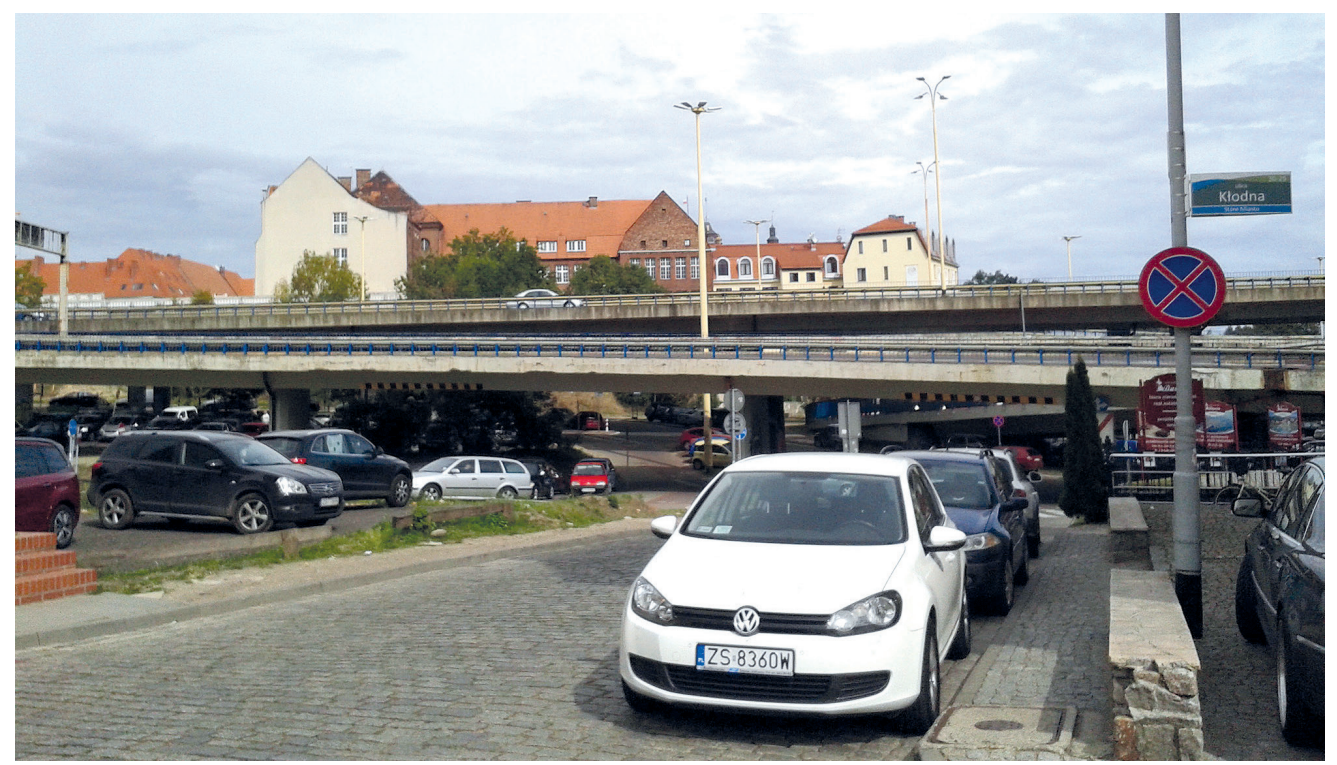

Fig. 7. Szczecin - a grade-separated junction of Nadodrzańska Artery (built right after World War II) and Zamkowa Route generates nobody's land in the very city centre, which dangerously hampers the creation of any compositional and functional link between both parts of the Old Town (photo by K. Dudzic-Gyurkovich) 


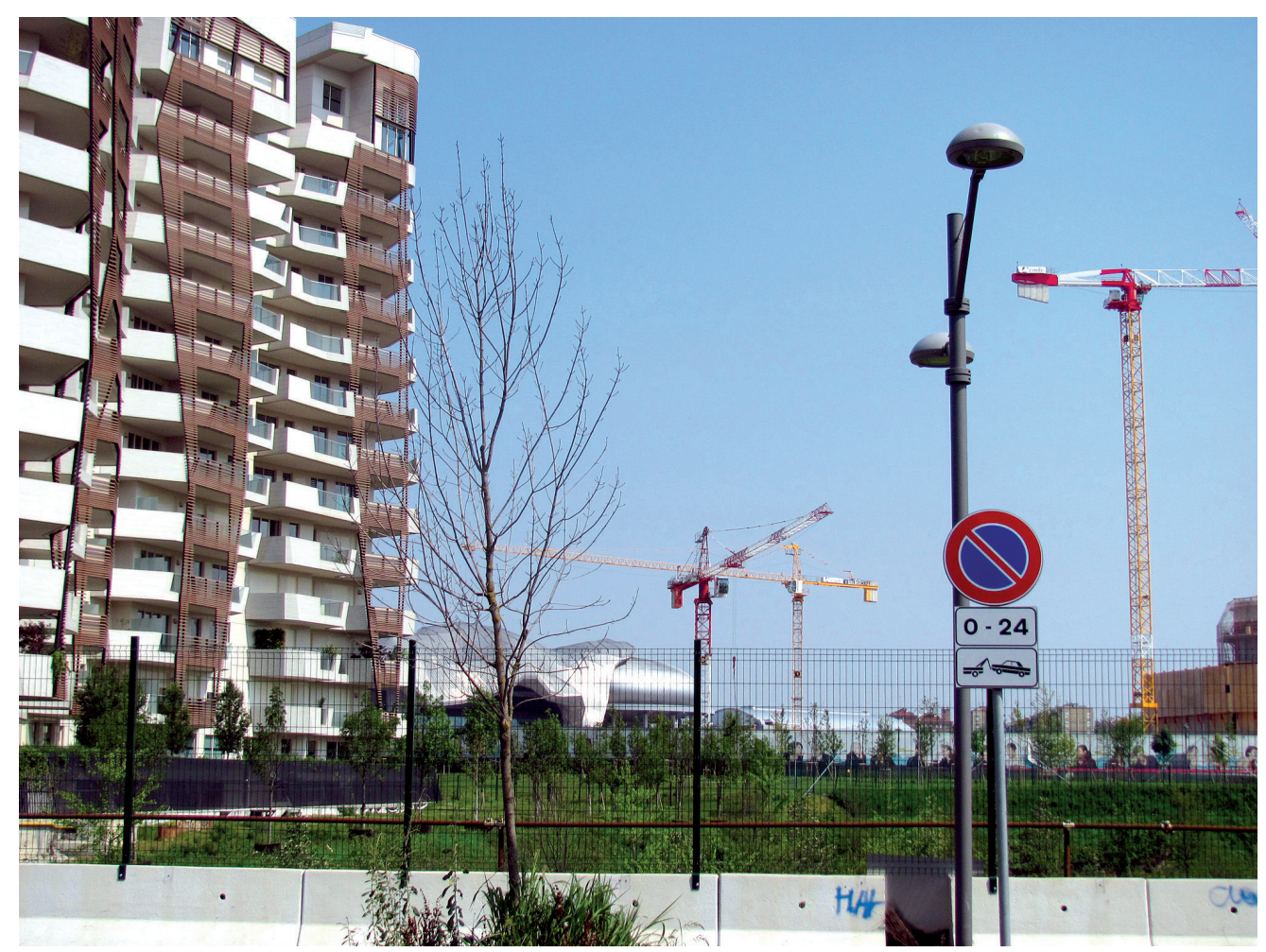

Fig. 8. Milan, part of a fenced and guarded complex of residential buildings 'City Life', under construction. The buildings visible in the picture have been designed in the studio of Daniel Liebeskind (photo by K. Dudzic-Gyurkovich)

\section{References}

[1] Augé M., Nie-miejsca: wprowadzenie do antropologii nowoczesności, PWN, Warszawa 2011.

[2] Batty M., Longley P.A., Fractal cities: A geometry of form and function, Academic Press, San Diego CA 1994.

[3] Batty M., New Science of Cities, MIT Press, Cambridge MA 2013.

[4] Benevolo L., Miasto w dziejach Europy, Wydawnictwo Krąg, Oficyna Wydawnicza Wolumen, Warszawa 1995.

[5] Billert A., Założenia, modele i planowanie polityki rozwoju miast. Próba konfrontacji dwóch światów Unii Europejskiej, [in:] Derejski K., Kubera J., Lisiecki S., Macyra R. (ed.), Deklinacja odnowy miast, Wydawnictwo Naukowe Wydziału Nauk Społecznych, UAM, Poznań 2012.

[6] Böhm A., O czynniku kompozycji w planowaniu przestrzeni, Wydawnictwo PK, Kraków 2016.

[7] Brugemann R., Sprawl - a compact history, University of Chicago Press, Chicago 2006.

[8] Burgers, J., De Gefragmenteerde Stad [The Fragmented City], Boom, Amsterdam 2002.

[9] Burgess E.W., Growth of the City, Introduction to a Research Project, [in:] Park R.E., Burgess E.W, McKenzie R.D., (ed.) The City, The University Of Chicago Press, Chicago, London 1925.

[10] Cohen J.-L., Le Corbusier, la planéte comme chantier, Textuel, Paris 2005. 
[11] Deakin M., (red.), Cerating Smart-er Cities, Oxon, Routlege 2013.

[12] De Cauter L., The Capsular Civilization: On the City in the Age of Fear, NAi Pub, Rotterdam 2004.

[13] Duany A., Plater-Zyberk E., SpeckJ., Suburban Nation. The Rise of Sprawl and the Decline of American Dream, North Point Press, New York, 2000.

[14] Dymnicka M., Przestrzeń publiczna a przemiany miasta, Wydawnictwo Naukowe Scholar, Warszawa 2013.

[15] Elin N., Postmodern Urbanism, Princeton Architectural Press, New York 1999.

[16] European Environment Agency EEA, Urban sprawl in Europe: the ignored challenge. EEA Report No 10/2006, European Environment Agency, 2006.

[17] Fainstein S., Gordon I., Harloe M., Divided cities: New York and London in the contemporary world, Basil Blackwell, Cambridge, MA 1992.

[18] Garlikowska M., Czynniki wptywające na postrzeganie transportu kolejowego w kategoriach niezawodności, [in:] Problemy Kolejnictwa, Vol. 165 (XII 2014), pp. 35-49.

[19] Harris C.D., Ullman E.L., The nature of cities, [in:] Annals of the American Academy of Political and Social Science, 242, 1945, pp. 7-17.

[20] Häussermann H., The End of European City?, [in:] European Review, Vol. 13, 2005, No. 2, pp. 237-249.

[21] Hillier B., Space is the machine: a configurational theory of architecture, Space Syntax, London 2007, E-book, http://spaceisthemachine.com (access: 02.02.2016).

[22] Hoyt H., The Structure and Growth of Residential Neighborhoods in American Cities, Federal Housing Administration, Washington DC 1939.

[23] Isin E.F., Theorizing the European city, [in:] Delanty G. (ed.) Handbook of Contemporary European Social Theory, Routledge 2006.

[24] Jacobs J., The Death and Life of Great American Cities, Modern Library Editions Random House Inc, New York1961.

[25] Jencks Ch., The Story of Post-Modernism: Five Decades of the Ironic, Iconic and Critical in Architecture, John Wiley \& Sons, Chichester 2011.

[26] Jenks M., Burton E., Williams K., The Compact City; A Sustainable Urban Form?, E \& FN Spon, London 1996.

[27] Koch F., The European City as a Transdisciplinary Concept: contradictions and potentials, [in:] Boletín de la Asociación de Geógrafos Españoles, No. 67, 2015, pp. 457-463.

[28] Kostof S., The city assembled : the elements of urban form through history, Thames and Hudson, London 1999.

[29] Kosiński W., Preliminaria badań nad problematyką: Piękno miasta, [in:] Przestrzeń i Forma, No. 10/2008 pp. 13-42.

[30] Krier L., The Architecture of Community, Island Press, Washington DC 2009.

[31] Lorens P., Porzadek architektoniczny i urbanistyczny jako element przestrzennego zagospodarowania kraju, [in:] Studia Regionalne i Lokalne, No. 3(21)/2005.

[32] Lorens P., Martyniuk-PęczekJ.(ed.),Wybranezagadnienia rewitalizacjimiast, Wydawnictwo Urbanista, Gdańsk 2009. 
[33] Lorens P., Mironowicz I., (ed.),Wybrane teorie urbanistyki współczesnej, Wydawnictwo Urbanista, Gdańsk 2013.

[34] Lynch K., Obraz miasta, Archivolta, Kraków 2010.

[35] Marcuse P., van Kempen R., Of states and cities: The partitioning of urban space, Oxford University Press, Oxford 2002.

[36] McKenzie R.D., The Ecological Approach to the Study of the Human Community, [in:] Park R.E., Burgess E.W, McKenzie R.D., (ed.) The City, The University Of Chicago Press, Chicago, London 1925.

[37] Mollenkopf J.H., Castells M., Dual City: Restructuring New York, Russell Sage Foundation, New York 1991.

[38] OECD, Green Growth Studies: Compact City Policies: A Comparative Assessment, OECD Publishing: Paris 2012.

[39] OECD, The Metropolitan Century: Understanding Urbanisation and its Consequences, OECD Publishing, Paris 2015.

[40] Panerai P., Castex J., Depaule J-C., Samuels I., Urban Forms: The Death and Life of Urban Block, Architectural Press, Oxford 2004.

[41] Paszkowski Z., Miasto idealne w perspektywie europejskiej i jego związi z urbanistyka wspótczesna, Universitas, Kraków 2012.

[42] Rowe C., Koetter F., Collage City, MIT Press, Cambridge MA 1983.

[43] Salingaros N., Principles of Urban Structure, Techne Press, Amsterdam 2005.

[44] Sennett R., The Fall of Public Man, Penguin Books, London, 2002.

[45] Tołwiński T., Urbanistyka T.1 - Budowa miasta w przeszłości, Wydawnictwo Zakładu Urbanistyki Politechniki Warszawskiej, Warszawa 1939.

[46] Trancik R., Finding Lost Space: Theories of Urban Design, Van Nostrand Reinhold Company, New York 1986.

[47] United Nations, Department of Economic and Social Affairs, Population Division, 2014.

[48] van Kempen R., Divided cities in the $21^{\text {st }}$ century: challenging the importance of globalisation, [in:] Journal of Housing and the Built Environment, 2007, 22, pp. 13-31.

[49] Weber M., The Nature of the City, [in:] Sennet R. (ed.), Classic Essays on the Culture of Cities, Prentice, Hall Inc., Englewood Cliffs, New York 1969.

[50] Whitehand J.W.R., British Urban Morphology: The Conzenian Tradition, [in:] Urban Morphology, 2001, 5(2), pp. 103-109.

[51] Williams K., Urban form and infrastructure: a morphological review, Future of cities: working paper, Foresight, Government Office for Science, 2014.

[52] Wirth L., Urbanism as a Way of Life, The American Journal Of Sociology, Vol. XLIV, No. 1, 1938, pp. 2-24.

[53] World Urbanization Prospects: The 2014 Revision, Highlights (ST/ESA/SER.A/352).

[54] Załuski D., Przekształcenia dworców kolejowych i terenów kolejowych na nowe funkcje miejskie, Politechnika Gdańska, Studio DZ, Gdańsk 2010.

[55] Zuziak Z.K, The Idea Of The City And Planning Theories, Technical Transactions, 12-A/2015, pp. 9-27.

[56] www.urbanform.org/glossary.html (access: 20.05.2017). 
[57] www.ectp-ceu.eu (access: 20.05.2017).

[58] www.who.int/gho/urban_health/situation_trends/urban_population_growth_text/en (access: 20.05.2017).

[59] www.fhwa.dot.gov/interstate/history.cfm (access: 20.05.2017).

[60] http://spaceisthemachine.com (access: 20.05.2017).

[61] http://libeskind.com/work/city-life (access: 20.05.2017). 